\title{
(6) OPEN ACCESS \\ Safe and effective pharmacotherapy in infants and preschool children: importance of formulation aspects
}

\author{
Diana A van Riet-Nales, ${ }^{1,2}$ Alfred F A M Schobben, ${ }^{1,2}$ Herman Vromans, ${ }^{2,3}$ \\ Toine C G Egberts, ${ }^{2,3}$ Carin M A Rademaker ${ }^{3}$
}

${ }^{1}$ Chemical Pharmaceutical Assessment (CFB), Medicines Evaluation Board in the Netherlands, Utrecht, The Netherlands

${ }^{2}$ Department of

Pharmacoepidemiology and Clinical Pharmacology, Utrecht University, Faculty of Science,

Utrecht Institute for

Pharmaceutical Sciences (UIPS), Utrecht, The Netherlands ${ }^{3}$ Department of Clinical Pharmacy, University Medical Centre Utrecht, Utrecht, The Netherlands

\section{Correspondence to}

Diana Alexandra van RietNales, Department of Chemical Pharmaceutical Assessment, Medicines Evaluation Board in the Netherlands, P. O. Box 8275, Utrecht 3503 RG, The Netherlands: da.v.riet@cbg-meb.nl

Received 1 May 2015 Revised 14 January 2016 Accepted 23 January 2016 Published Online First 15 March 2016

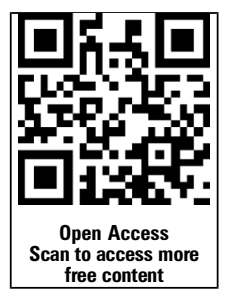

CrossMark

To cite: van Riet-Nales DA, Schobben AFAM

Vromans $\mathrm{H}$, et al. Arch Dis Child 2016;101:662-669.

\section{ABSTRACT}

Safe and effective paediatric pharmacotherapy requires careful evaluation of the type of drug substance, the necessary dose and the age-appropriateness of the formulation. Generally, the younger the child, the more the attention that is required. For decades, there has been a general lack of (authorised) formulations that children are able to and willing to take. Moreover, little was known on the impact of pharmaceutical aspects on the age-appropriateness of a paediatric medicine. As a result of legislative incentives, such knowledge is increasingly becoming available. It has become evident that rapidly dissolving tablets with a diameter of $2 \mathrm{~mm}$ (mini-tablets) can be used in preterm neonates and nonrapidly dissolving $2 \mathrm{~mm}$ mini-tablets in infants from 6 months of age. In addition, uncoated $4 \mathrm{~mm}$ minitablets can be used in infants from the age of 1 year. Also, there is some evidence that children prefer minitablets over a powder, suspension or syrup. Other novel types of age-appropriate oral formulations such as orodispersible films may further add to the treatment possibilities. This review provides an overview of the current knowledge on oral formulations for infants and preschool children, the advantages and disadvantages of the different types of dosage forms and the age groups by which these can likely be used.

\section{INTRODUCTION}

For decades, the availability of medicines with an approved paediatric indication has been lagging behind those for adults, there has been a general lack of formulations that children are able to and willing to take, and the younger the child, the poorer the situation. ${ }^{1}$ All this has resulted in high off-label and unlicensed prescription rates, which increase the risk of harm. ${ }^{2}$

A range of initiatives have been undertaken to improve this situation. From 1994, the US government has implemented several legislative frameworks to increase paediatric drug labelling ultimately resulting in the Food and Drug Administration Safety and Innovation Act (FDASIA). ${ }^{3}$ In 2007, the European Union installed a Paediatric Regulation to improve the health of the children of Europe, for example, by increasing the availability of authorised and well-designed medicines for children. ${ }^{4}$ In the same year, the WHO started a programme to make medicines child sized. ${ }^{5}$ The European Regulation enforces the pharmaceutical industry to consider children at an early phase in the development of a medicine with a new active substance, new indication or new route of administration, unless a waiver of deferral applies, and to develop a paediatric investigation plan (PIP) describing the proposals and timelines for the clinical trials in children of different ages as well as the formulation(s) intended for future marketing. ${ }^{4}$

All these provisions have resulted in an increased focus on paediatric formulation development worldwide. In 2012, WHO issued a 'points to consider' document in pharmaceutical development. ${ }^{6}$ Following an earlier reflection paper, in 2013, the European Medicines Agency (EMA) published guidance requiring industry to justify all aspects in the design of a paediatric medicine at the time of marketing authorisation and, where appropriate, the PIP. The guideline indicates that companies may need to develop more than a single formulation to treat children of different ages and disease statuses. Aspects to be justified include the selection of the route of administration, type of dosage form, product strength/concentration, dosing frequency, excipient composition, container closure system, administration device, user instruction and patient acceptability. ${ }^{7}$ In order to meet the regulatory expectations and taking advantage of increased funding opportunities, the provisions have also fostered science and innovative, collaborative research initiatives. ${ }^{4}{ }^{8}$ Currently, major progress has been made resulting in, for example, innovative approaches to drug delivery, especially for young(er) children. ${ }^{9}$ Therefore, this review provides an overview of current knowledge on oral formulations for infants and preschool children, the advantages and disadvantages of the different types of oral formulations and the age groups by which these can likely be used.

\section{Oral formulations}

Oral administration may be directed at a systemic effect following absorption, or at a local effect in the gastrointestinal tract. ${ }^{10} 11$ It is defined as the taking of a medicine by means of swallowing and must be differentiated from oromucosal administration, which encompasses the use of medicines such as buccal tablets and sublingual sprays in the oral cavity or throat. ${ }^{12}$

Regardless of the target patient population, oral formulations can be divided into those providing flexible doses, such as liquids, powders and granules, and those providing unit doses, such as tablets and capsules (tables 1-5). In addition, they can be divided into formulations that are liquid or (semi) solid on manufacture by the pharmaceutical industry, on administration or on swallowing. ${ }^{17}$ Although oral 
Table 1 Liquid formulations for young children: type of dosage form, age group and main user advantages and disadvantages*

\begin{tabular}{|c|c|c|c|c|c|}
\hline \multicolumn{6}{|c|}{ Formulations manufactured and administered and swallowed as a liquid } \\
\hline Dosage form & $\begin{array}{l}\text { Formulation } \\
\text { characteristics }\end{array}$ & $\begin{array}{l}\text { Likely to be } \\
\text { used from }\end{array}$ & Main (user) advantages & Main (user) disadvantages & $\begin{array}{l}\text { Specific } \\
\text { reference }\end{array}$ \\
\hline Solution & Immediate releaset & (Term) birth & $\begin{array}{l}\text { Easy to swallow } \\
\text { Flexible dosing }\end{array}$ & $\begin{array}{l}\text { Potential need for harmful solvents } \\
\text { Potential short product/in-use shelf-life } \\
\text { Potential need for storage in refrigerator } \\
\text { Common need for preservation } \\
\text { Common need for taste optimisation } \\
\text { Dosing volume may be high } \\
\text { Need for suitable dosing device } \\
\text { Risk for errors when measuring the dose } \\
\text { Risk of spillage upon administration } \\
\text { Portability may be a problem }\end{array}$ & 91314 \\
\hline Emulsion (including microemulsion) & Immediate releaset & (Term) birth & $\begin{array}{l}\text { As solution } \\
\text { Reduced need of harmful } \\
\text { solvents }\end{array}$ & $\begin{array}{l}\text { As solution, but } \\
\text { Risk for incorrect shaking/emulsion } \\
\text { break up resulting in incorrect doses }\end{array}$ & 914 \\
\hline Suspension & $\begin{array}{l}\text { Immediate } \dagger \text { or } \\
\text { modified } \ddagger \text { release }\end{array}$ & (Term) birth & $\begin{array}{l}\text { As solution, but } \\
\text { Reduced need of harmful } \\
\text { solvents } \\
\text { Possibility of particle } \\
\text { coating for taste masking }\end{array}$ & $\begin{array}{l}\text { As solution, but } \\
\text { Mouth feel may be an issue } \\
\text { Risk for incorrect shaking/segmentation } \\
\text { resulting in incorrect doses }\end{array}$ & 91314 \\
\hline $\begin{array}{l}\text { Concentrate for oral liquid } \\
\text { (solution, emulsion, suspension) }\end{array}$ & $\begin{array}{l}\text { As solution/emulsion/ } \\
\text { suspension }\end{array}$ & (Term) birth & $\begin{array}{l}\text { As solution/emulsion/ } \\
\text { suspension, but } \\
\text { Reduced volume for } \\
\text { storage and transport } \\
\text { Fewer stability problems }\end{array}$ & $\begin{array}{l}\text { As solution/emulsion/suspension, but } \\
\text { Need for reconstitution } \\
\text { Need for clean water by patient/ } \\
\text { pharmacist }\end{array}$ & 14 \\
\hline $\begin{array}{l}\text { Drops (solution, emulsion, } \\
\text { suspension) }\end{array}$ & Immediate releaset & (Term) birth & $\begin{array}{l}\text { As concentrate for oral liquid, } \\
\text { but } \\
\text { Low dosing volume }\end{array}$ & $\begin{array}{l}\text { As solution/emulsion/suspension, but } \\
\text { Variable drop size } \\
\text { Counting errors }\end{array}$ & 1415 \\
\hline
\end{tabular}

administration is a favourable route to administer medicines, it cannot always be used. For example, because of stability issues or inadequate absorption eg, human growth factor. Moreover, children may not accept some types of oral formulations because of swallowing difficulties, recalcitrance or bad taste..$^{10} 17$ Non-oral routes of administration, for example, nasal, rectal or (trans) dermal, may provide a valuable alternative. However, children may not accept these routes as well. Administration by injection may be used as a last resort for children who are critically ill. ${ }^{79}$

\section{Oral liquid formulations}

Oral liquid formulations such as solutions and suspensions are commonly given to young children because they are easy to swallow. ${ }^{1}{ }^{10}$ However, they are normally packed in multidose containers requiring preservation and accurate dose measurements. Dosing accuracy is highly determined by the volume to be measured and the type of dosing device. A minimum volume for accurate dosing with an oral syringe, measuring spoon or cup is yet to be defined. ${ }^{7}{ }^{16}$ As formulations may be marketed for a wide patient population without a dosing device or with a device that is suitable for some doses only, it is essential that healthcare professionals ensure that children will obtain a dosing device that is appropriate to deliver the recommended dose, and that any inappropriate devices are removed from the packaging. ${ }^{38}$ This approach will help reducing the risk for 10 fold overdosing.

Oral liquid medicines, for example, tramadol, clonazepam, may be marketed as drops for children of different ages. Their main benefits include a low dosing volume, ease of swallowing and dosing flexibility. However, drops require careful consideration when dosing is critical in view of the risk of drop size variation and counting errors. ${ }^{7}{ }^{15}$ It is recommended that nurses and parents are clearly instructed to hold the dropper in a vertical position. ${ }^{15}$ Acknowledging that the risk of dosing errors adds to the general disadvantages of oral liquid formulations, there is a need for better administration modalities. ${ }^{7}$

\section{Formulations that are swallowed as a liquid or pulp}

Oral formulations may be designed in a form that is solid upon manufacture, yet liquid upon administration to the child, for example, dispersible tablets, effervescent tablets and granules for oral solution. ${ }^{17} 20$ The main reason for such approach is the limited stability of the active substance in the liquid form, the need for dosing flexibility or the wish to ease swallowing. Easy swallowing may also be achieved by orodispersible formulations such as orodispersible tablets, granules and lyophilisates. ${ }^{20} 21$ These dosage forms are solid upon manufacture and administration, yet they rapidly disintegrate in the mouth so that the child actually swallows a liquid or pulp.

\section{Oral solid formulations}

Oral solid formulations are commonly manufactured as powders, granules, capsules or tablets. Granules can be coated in order to modify the release or to mask the taste of the active substance. Powders and granules are easy to swallow for infants and preschool children, yet children may not like their mouth 
Table 2 Solid formulations for young children that are liquid upon intake: type of dosage form, age group and main user advantages and disadvantages*

\section{Manufactured as a solid, but administered and swallowed as a liquid}

\begin{tabular}{|c|c|c|c|c|c|}
\hline Dosage form & $\begin{array}{l}\text { Formulation } \\
\text { characteristics }\end{array}$ & Likely to be used from & Main (user) advantages & Main (user) disadvantages & $\begin{array}{l}\text { Specific } \\
\text { reference }\end{array}$ \\
\hline $\begin{array}{l}\text { Powder/granules for oral liquid } \\
\text { (solution, suspension) in multiple } \\
\text { dose container }\end{array}$ & $\begin{array}{l}\text { Immediate† or } \\
\text { modified } \ddagger \text { release }\end{array}$ & (Term) birth & $\begin{array}{l}\text { As solution/suspension, but } \\
\text { Less risk short product } \\
\text { shelf-life } \\
\text { Reduced need of harmful } \\
\text { excipients }\end{array}$ & $\begin{array}{l}\text { As solution/suspension, but } \\
\text { Need clean water patient/ } \\
\text { pharmacist } \\
\text { Compatibility with drink other } \\
\text { than water may be an issue }\end{array}$ & 9 \\
\hline $\begin{array}{l}\text { Powder/granules for oral liquid } \\
\text { (solution, dispersion, suspension) in } \\
\text { single dose container (often sachet) }\end{array}$ & $\begin{array}{l}\text { Immediate } \nmid \text { or } \\
\text { modified } \ddagger \text { release }\end{array}$ & $\begin{array}{l}\text { Solution/suspension } \\
\text { (term) birth; dispersion } \\
\text { probably } 3 \text { months }\end{array}$ & $\begin{array}{l}\text { As powder/granules for oral } \\
\text { liquid (solution, suspension) in } \\
\text { multiple dose container, but } \\
\text { Good portability } \\
\text { No need of dosing device } \\
\text { No need of refrigerated } \\
\text { storage of reconstituted } \\
\text { product }\end{array}$ & $\begin{array}{l}\text { As powder/granules for oral liquid } \\
\text { (solution, suspension) in multiple } \\
\text { dose container, but } \\
\text { Reduced dosing flexibility; } \\
\text { various strengths may be } \\
\text { required } \\
\text { Mouth feel dispersion may be } \\
\text { less than suspension }\end{array}$ & 9 \\
\hline $\begin{array}{l}\text { Dispersible tablets (dispersion } \\
\text { intended prior to administration) }\end{array}$ & Immediate releaset & Probably 3 months & $\begin{array}{l}\text { As powder/granules for oral } \\
\text { liquid (dispersion) in single dose } \\
\text { container }\end{array}$ & $\begin{array}{l}\text { As powder/granules for oral liquid } \\
\text { (dispersion) in single dose } \\
\text { container, but } \\
\text { Potential need for rinsing } \\
\text { administration device }\end{array}$ & 91718 \\
\hline $\begin{array}{l}\text { Soluble tablets (dissolution intended } \\
\text { prior to administration) }\end{array}$ & Immediate releaset & (Term) birth & $\begin{array}{l}\text { As powder/granules for oral } \\
\text { liquid (solution) in single dose } \\
\text { container }\end{array}$ & $\begin{array}{l}\text { As powder/granules for oral liquid } \\
\text { (solution) in single dose container }\end{array}$ & 917 \\
\hline $\begin{array}{l}\text { Effervescent dosage form (powder, } \\
\text { granules, tablet) }\end{array}$ & Immediate release $†$ & $\begin{array}{l}3 \text { months, possibly } \\
\text { younger }\end{array}$ & $\begin{array}{l}\text { As powder/granules for oral } \\
\text { liquid (solution) in single dose } \\
\text { container }\end{array}$ & $\begin{array}{l}\text { As powder/granules for oral liquid } \\
\text { (solution) in single dose container } \\
\text { May require large volume of } \\
\text { water } \\
\text { Increased risk of tooth erosion } \\
\text { Risk for overload of sodium and } \\
\text { bicarbonate }\end{array}$ & 1719 \\
\hline
\end{tabular}

* Recommendations on age are based on the reflected literature, considerations of the European Medicines Agency (EMA) guideline on the pharmaceutical development of medicines for paediatric use $\mathrm{e}^{16}$ and expert knowledge of marketing authorisations.

tImmediate release administration implies the general disadvantage that dosing frequencies may be high. Although not intended, immediate release formulations may normally be chewed, crumbled or crushed. However, this may affect taste.

¥Modified release administration implies the general advantage that dosing frequencies may be reduced. Depending on the type of modified release, these formulations may sometimes be chewed or crumbled; however, they may never be crushed to powder.

feel. Moreover, clinical evidence indicates that powders and granules are commonly given with food or drink to ease swallowing even when the joint intake of the medicine with food or drink is not part of the marketing authorisation, that is, not recommended in the user instruction. ${ }^{7} 1039$ In the majority of cases, the lack of such a recommendation will be based on the lack of data justifying the adequate stability (chemical, physical) and bioavailability of the medicated food. ${ }^{7} 40$

Capsules can be either soft or hard. Hard capsules can be filled with powder or (coated) granules. They are normally intended for direct swallowing, however some may be opened and their contents given as such. ${ }^{7}$ Soft capsules are often filled with liquid and water insoluble substances. Some may be opened as well, however this practice is more likely to impact bioavailability. $^{7}$

Tablets can be either coated or uncoated and for immediate or modified (gastroresistant, extended, prolonged) release. Immediate tablets can be manufactured as chewing tablets to enable easy swallowing. Otherwise, tablets are intended to be swallowed intact. Nevertheless, immediate tablets can be chewed, crumbled or crushed without any relevant impact on the medicine's stability and bioavailability, although taste may be significantly deteriorated. The latter is more likely with immediate tablets that have a film-coating for taste masking. Modified release tablets can be achieved through different principles. When achieved through a dedicated coating of the tablet or an osmotic pump system, it is evident that the tablet must be swallowed intact. If the modified release character is based on coated granules, the effect of chewing and crumbling may be less drastic; however in the majority of cases there is still a need to take these formulations intact. In any case, these tablets should not be crushed to powder. ${ }^{7}$

So far, immediate and modified release tablets are rarely developed for use in infants and preschool children as historic opinions suggest that young children cannot swallow tablets intact. ${ }^{11}$ However, there is increasing evidence that small tablets (mini-tablets) can be swallowed safely by children from a very young age (figure 1). ${ }^{41}$ An overview of the current evidence is provided by Liu et $a l^{17}$ and Aleksovski et al. ${ }^{41}$ For example, Klingmann et al found that uncoated and coated $2 \mathrm{~mm}$ tablets are well accepted in children from 6 months onwards and that the uncoated mini-tablets were even better accepted than a syrup. $^{28}$ The same authors also showed that rapidly dissolving uncoated $2 \mathrm{~mm}$ tablets are were well taken by (pre)term neonates. The tablets were placed in the cheek pouch and swallowing was facilitated by offering the child a drink of the parents' choice (breast milk, milk, tea, water, maltodextrine). Actually, the tablets were even better accepted than $0.5 \mathrm{~mL}$ of an oral syrup. $^{22}$ In addition, Kluk et al ${ }^{29}$ showed that children from 2 years on are able to swallow several $2 \mathrm{~mm}$ mini-tablets as a single dose, eventually with the help of a gliding agent. Although the repeatability of these findings in the domiciliary 
Table 3 Solid formulations for young children that are liquid upon swallowing: type of dosage form, age group and main user advantages and disadvantages*

\begin{tabular}{|c|c|c|c|c|c|}
\hline \multicolumn{6}{|c|}{ Manufactured and administered as a solid, but swallowed as a liquid } \\
\hline Dosage form & $\begin{array}{l}\text { Formulation } \\
\text { characteristics }\end{array}$ & $\begin{array}{l}\text { Likely to be used } \\
\text { from }\end{array}$ & Main (user) advantages & Main (user) disadvantages & \\
\hline $\begin{array}{l}\text { Orodispersible granules in single } \\
\text { dose packaging }\end{array}$ & Immediate releaset & Birth & $\begin{array}{l}\text { Easy swallowing } \\
\text { Easy to use } \\
\text { Water not required for intake } \\
\text { Flexible dosing } \\
\text { Good portability } \\
\text { Can be stored outside refrigerator } \\
\text { Likely to improve patient } \\
\text { acceptability and adherence }\end{array}$ & $\begin{array}{l}\text { Potential need of excipients of } \\
\text { unknown safety profile } \\
\text { Taste masking is challenging } \\
\text { Fragile product, requires careful } \\
\text { handling } \\
\text { Critical packaging and storage } \\
\text { conditions } \\
\text { Risk for delayed market entry as } \\
\text { technologies may be under patent }\end{array}$ & 2021 \\
\hline \multirow[t]{2}{*}{ Orodispersible tablets } & $\begin{array}{l}\text { Mini-tablets }(2-5 \mathrm{~mm}) \\
\text { Immediate releaset }\end{array}$ & $\begin{array}{l}2 \mathrm{~mm} \text { (pre)term } \\
\text { birth; } \\
3-4 \mathrm{~mm} \text { probably at } \\
\text { least from } 6 \text { months }\end{array}$ & $\begin{array}{l}\text { As orodispersible granules, but } \\
\text { limited risk for spillage } \\
\text { Easy administration }\end{array}$ & $\begin{array}{l}\text { As orodispersible granules, but } \\
\text { Fixed dose } \\
\text { tablets } \\
\text { Increased risk for accidental } \\
\text { swallowing } \\
\text { Acceptability in domiciliary } \\
\text { setting not yet confirmed }\end{array}$ & $20-22$ \\
\hline & $\begin{array}{l}\text { Conventionally sized } \\
(>5 \mathrm{~mm}) \text { immediate } \\
\text { releaset }\end{array}$ & $\begin{array}{l}5-8 \mathrm{~mm} \text { at least } \\
1 \text { year, probably } \\
\text { older }\end{array}$ & As orodispersible mini-tablets & $\begin{array}{l}\text { As orodispersible mini-tablets, but } \\
\text { May be accepted in older } \\
\text { children only } \\
\text { Reduced dosing flexibility; } \\
\text { various strengths may be } \\
\text { required }\end{array}$ & 202123 \\
\hline $\begin{array}{l}\text { Orodispersible lyophilisate } \\
\text { (=freeze dried solution/ } \\
\text { suspension) }\end{array}$ & Immediate releaset & Possibly from birth & As orodispersible tablets & $\begin{array}{l}\text { As orodispersible tablets, but } \\
\text { Product damage upon handling } \\
\text { Need for peel off blister packs } \\
\text { Higher price than conventional } \\
\text { dosage forms }\end{array}$ & 2021 \\
\hline Orodispersible films & Immediate releaset & Possibly from birth & $\begin{array}{l}\text { As orodispersible granules, but easy } \\
\text { to manufacture in various strengths }\end{array}$ & As orodispersible tablets & 202124 \\
\hline
\end{tabular}

setting remains to be investigated, we showed that $4 \mathrm{~mm}$ uncoated placebo mini-tablets are well accepted in children older than 1 year when given by their parents at home. Actually, we found that the $4 \mathrm{~mm}$ mini-tablets were generally better accepted than an oral powder, suspension and solution. ${ }^{25}$ Mini-tablets may also be developed to provide modified release. ${ }^{41}$

\section{Novel approaches to paediatric formulation development}

Novel types of oral solid dosage forms are increasingly being investigated to realise safe and effective medications that are also (more) easy to use by children, parents and caregivers, for example, orodispersible mini-tablets, pulptablets, pellets, oral dispersible films, oral gels and medicated nipple-shield. ${ }^{17} 2042$ Pulptablets are intended to be put on the spoon where they form a pulp upon contact with a small portion of water. This dosage form combines the advantages of the manufacture of a solid formulation, such as limited need for harmful excipients, good stability and good portability, with easy swallowing by the child, while at the same time limiting the risk of spillage.

Orodispersible films consist of a water-dissolving polymer that adheres to the mucosa upon contact with the saliva. Oral administration is realised by swallowing medicated saliva. Orodispersible films may also be intended for oromucosal use. ${ }^{2142}$

Another approach to oral administration in children is provided by Bar-Shalom. The author indicates a need for a flexible formulation that is acceptable to children of any age and health status. He proposes an automated compounding concept consisting of a pulp-like carrier, microencapsulated drug and a dispensing robot by which a pharmacy can deliver any dose upon request. However, the application of such an approach may require rethinking of commonly applied clinical, regulatory and marketing principles. ${ }^{37}$

\section{Excipients}

Excipients form the major constituent of the majority of medicines. They serve different functions as, for example, filler, binder, desintegrans, preservative, antioxidant, sweetener, taste masker, colouring agent and coating agent. Excipients are anticipated to have no pharmacological action. However, it is increasingly recognised that excipients may exert a different safety profile in children due to the immaturity of their organ and body systems. Thus, excipients that are safe for use in adults and older children may not necessarily be so when used in (younger) children. ${ }^{73}$ As this phenomenon has gained little attention for decades, the use of excipients in authorised, off-label and pharmacy compounded paediatric medicines is now subject to increased concern and re-evaluation. ${ }^{43} 44$

Currently, the European Paediatric Formulation Initiative (EuPFI) is developing an open access Safety and Toxicity of Excipients for Paediatrics (STEP) database. The database provides an easy searchable tool of the pharmacology, toxicology 
Table 4 Solid formulations for young children: type of dosage form, age group and main user advantages and disadvantages*

\begin{tabular}{|c|c|c|c|c|c|}
\hline \multicolumn{6}{|c|}{ Manufactured and administered and swallowed as a solid (eventually with a slug of water to ease swallowing) } \\
\hline Dosage form & $\begin{array}{l}\text { Formulation } \\
\text { characteristics }\end{array}$ & $\begin{array}{l}\text { Likely to be } \\
\text { used from }\end{array}$ & Main (user) advantages & Main (user) disadvantages & \\
\hline Powder & Immediate releaset & $\begin{array}{l}\text { From } 6 \text { months, } \\
\text { probably younger }\end{array}$ & $\begin{array}{l}\text { Easy to swallow } \\
\text { Flexible dosing }\end{array}$ & $\begin{array}{l}\text { Grittiness/taste may be an issue, may be given with food } \\
\text { or drink even if food compatibility had not been shown, } \\
\text { less accepted than mini-tablets }\end{array}$ & 25 \\
\hline $\begin{array}{l}\text { Granules/pellets/ } \\
\text { sprinkles }\end{array}$ & $\begin{array}{l}\text { Immediate } \dagger \text { or modified } \neq \\
\text { release }\end{array}$ & $\begin{array}{l}\text { From } 6 \text { months, } \\
\text { probably younger }\end{array}$ & $\begin{array}{l}\text { As powder, but } \\
\text { Suitable for coating and taste } \\
\text { masking } \\
\text { May be combined with novel } \\
\text { sipping administration } \\
\text { modality }\end{array}$ & $\begin{array}{l}\text { As powder, but } \\
\text { Potential need for packaging/dispensing system } \\
\text { Better accepted than drops }\end{array}$ & 2627 \\
\hline \multirow[t]{2}{*}{$\begin{array}{l}\text { Mini-tablet } \\
(1-4 \mathrm{~mm})\end{array}$} & $\begin{array}{l}\text { 2-mm coated or uncoated } \\
\text { (placed on tongue); } \\
\text { immediate releaset }\end{array}$ & $\begin{array}{l}6 \text { months, } \\
\text { possibly younger }\end{array}$ & $\begin{array}{l}\text { Easy to swallow } \\
\text { Flexible dosing } \\
\text { Can be stored outside refrigerator } \\
\text { Good portability } \\
\text { Several tablets can be taken with } \\
\text { a jelly as a single dose } \\
\text { Tablet better accepted than syrup }\end{array}$ & $\begin{array}{l}\text { Possible need for tablet dispenser } \\
\text { Acceptability in domiciliary setting not yet confirmed }\end{array}$ & $\begin{array}{l}6 \\
28-30\end{array}$ \\
\hline & $\begin{array}{l}\text { 4-mm (given at home by } \\
\text { parents); immediate } \\
\text { releaset }\end{array}$ & $\begin{array}{l}1 \text { year, possibly } \\
\text { younger }\end{array}$ & $\begin{array}{l}\text { As } 2 \mathrm{~mm} \text { tablet } \\
\text { Better accepted than syrup, } \\
\text { suspension, powder } \\
\text { Long experience with vitamin D } \\
\text { and fluoride tablets }\end{array}$ & $\begin{array}{l}\text { As } 2 \mathrm{~mm} \text { tablet, but } \\
\text { No need for tablet dispenser }\end{array}$ & 25 \\
\hline $\begin{array}{l}\text { Tablets } \\
\text { (conventional size) }\end{array}$ & 5-8 mm Immediate release & 2 years & $\begin{array}{l}\text { As granules/pellets/sprinkles, but } \\
\text { Reduced dosing flexibility } \\
\text { Reduced swallowability; can } \\
\text { beimproved by training }\end{array}$ & $\begin{array}{l}\text { Acceptability will depend on size, shape, coating, child } \\
\text { characteristics } \\
\text { Reduced dosing flexibility; various strengths may be } \\
\text { requiredPotential risk of choking }\end{array}$ & 31 \\
\hline Chewable tablets & Immediate releaset & $\begin{array}{l}2 \text { years, possibly } \\
\text { younger }\end{array}$ & $\begin{array}{l}\text { Easier to swallow than } \\
\text { conventional tablets } \\
\text { Water is not required }\end{array}$ & $\begin{array}{l}\text { Reduced dosing flexibility; various strengths may be } \\
\text { required } \\
\text { Mouth feel and taste may be an issue } \\
\text { Controlled release is challenging } \\
\text { Potential need of excipients of unknown safety profile } \\
\text { Risk of overdose if used as candy } \\
\text { Risk of choking in young children }\end{array}$ & 3233 \\
\hline Capsules & Hard or soft & Probably 2 years & $\begin{array}{l}\text { In case of swallowing difficulties, } \\
\text { sometimes contents can be taken } \\
\text { as such }\end{array}$ & $\begin{array}{l}\text { Various dose strengths may be required } \\
\text { No data on child acceptability in relation to size/shape } \\
\text { available }\end{array}$ & 7 \\
\hline
\end{tabular}

and safety data of a selected group of excipients as published in peer-reviewed journals, government reports and other databases. $^{45}$ Also, the EMA has started a re-evaluation of the need for information in the medicine's product label. The discussion focuses on a specific set of excipients that are known for or have been associated with increased harm in humans, for example, benzalkonium chloride, benzoic acid and benzoates, benzylalcohol, cyclodextrins, ethanol and propylene glycol. The first results are published as Questions and Answers (Q\&A) papers on the EMA website, together with the background review. ${ }^{46}$ In addition, the guideline on the pharmaceutical development of medicines for paediatric use includes a 'points to consider' paragraph indicating the information sources that can be considered when deciding on the suitability of an excipient for inclusion in a paediatric formulation.

\section{Well-designed paediatric formulations}

Good pharmaceutical development implies that the selection of a paediatric medicine is based on an integrated approach balancing, for example, the advantages and disadvantages of the different routes of administration and formulation options including the safety of excipients, usability, manufacturability, cost and patient access (figure 2). ${ }^{20}{ }^{48}$ However, this does not imply that the marketing authorisation of a paediatric medicine is refused or suspended when a product does not have ideal characteristics. ${ }^{1}$ Thus, children will benefit from a careful comparison of the different routes of administration, types of dosage forms and formulations (trade marks) that are available for administering a certain active moiety. Such comparison is especially important in case of multiple medication use and when interchanging medicines upon drug shortages, altered reimbursement rules or transitions of care. The relevant product information can be obtained from the open access databases of the European regulatory authorities or paediatric formularies.

Currently, the Biopharmaceutic Classification System (BCS) system classifies a drug into four groups: class I high permeability and high solubility; class II high permeability and low solubility; class III low permeability and high solubility; class IV low permeability and low solubility. The system is commonly used by industry to support formulation changes, whereas bioequivalence studies may be waived for class I drugs. However, it is increasingly acknowledged that the BCS testing conditions are 
Table 5 Novel types of oral dosage forms for young children: type of dosage form, age group and main user advantages and disadvantages* Novel types of oral dosage forms

\begin{tabular}{|c|c|c|c|c|c|}
\hline Dosage form & $\begin{array}{l}\text { Formulation } \\
\text { characteristics }\end{array}$ & $\begin{array}{l}\text { Likely to be used } \\
\text { from }\end{array}$ & Main (user) advantages & Main (user) disadvantages & \\
\hline $\begin{array}{l}\text { Medicated spoon that forms oral } \\
\text { pulp }\end{array}$ & Immediate releaset & Probably 4-6 months & $\begin{array}{l}\text { Easy to swallow } \\
\text { Easy handling }\end{array}$ & $\begin{array}{l}\text { Various strength may be required } \\
\text { Need for clean water by patient }\end{array}$ & 20 \\
\hline Multiple scored tablet & IMMEDIATE release† & 1 month & $\begin{array}{l}\text { As tablet but } \\
\text { Better dosing flexibility }\end{array}$ & $\begin{array}{l}\text { As tablet but } \\
\text { Need for dosing accuracy upon } \\
\text { breaking } \\
\text { Acceptability parts depend on } \\
\text { size/shape }\end{array}$ & 34 \\
\hline Milk-based oral liquid formulation & Immediate releaset & (Term) birth & As liquid formulation & $\begin{array}{l}\text { As liquid formulation, but } \\
\text { Solubility and compatibility need } \\
\text { attention }\end{array}$ & 35 \\
\hline Nipple-shield drug delivery device & Immediate releaset & (Term) birth & & For use in breastfed children only & 36 \\
\hline $\begin{array}{l}\text { Robot system using } \\
\text { microencapsulated drug }\end{array}$ & $\begin{array}{l}\text { Immediate } † \text { or modified } \neq \\
\text { release }\end{array}$ & $\begin{array}{l}6 \text { months, possibly } \\
\text { younger }\end{array}$ & $\begin{array}{l}\text { As for granules, but } \\
\text { Swallowed as a pulp } \\
\text { One dosage unit contains all } \\
\text { drugs prescribed }\end{array}$ & $\begin{array}{l}\text { Cost only acceptable if adopted on } \\
\text { a wide scale }\end{array}$ & 37 \\
\hline
\end{tabular}

not appropriate to young children, for example, because of a change in the ratio between paediatric dose and gastric volumes over growth. In fact, Batchelor et al ${ }^{49}$ showed that drugs may shift to another class in the BCS when the testing conditions are altered to better reflect child physiology. As a consequence, they considered that there is a need for an age-specific BCS system to support paediatric formulation development.

\section{Formulation acceptability}

Child acceptability involves the overall ability and willingness of the child to use a medicine as intended. ${ }^{7}{ }^{17}$ It is mainly determined by recalcitrance and the organoleptic properties of the formulation, such as taste, aftertaste, smell, texture, appearance and colour. $^{7} 1743$ Acknowledging that many active substances have a bad taste, this implies the need for adequate measures in the pharmaceutical target product quality profile. ${ }^{43}$ In addition, child acceptability and adherence rates may be influenced by other aspects in the pharmaceutical design of the medicine, for example, type of dosing device (spoon, oral syringe) or dosing frequencies. ${ }^{3950}$ As young children are likely to depend on a caregiver for

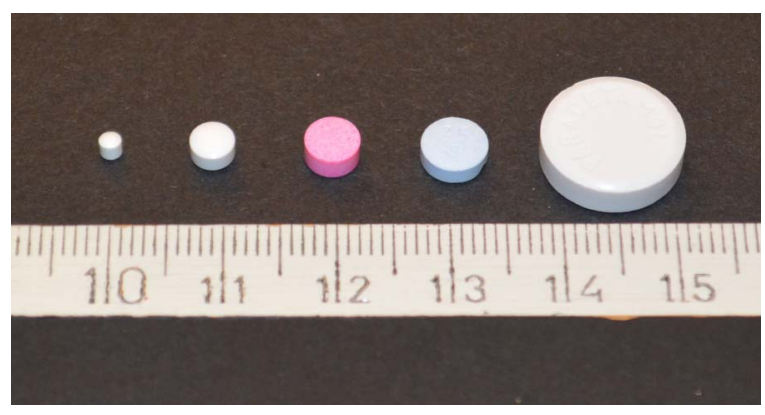

Figure 1 Tablets of different sizes. From left to right: $2 \mathrm{~mm}$ mini-tablet; $4 \mathrm{~mm}$ mini-tablet; $5 \mathrm{~mm}$ tablet (fludrocortisone acetate $0.0625 \mathrm{mg}$ ); $6 \mathrm{~mm}$ tablet (thyrax duotab $0.025 \mathrm{mg}$ ); $13 \mathrm{~mm}$ tablet (paracetamol $500 \mathrm{mg}$ ). drug administration, parent and caregiver acceptability may be of equal importance. ${ }^{16} 25$ Aspects to be considered involve health literacy, anticipated child acceptability and usability factors. ${ }^{11} 17$

Adequate user acceptability and drug adherence are key to safe and effective paediatric pharmacotherapy. Therefore, these aspects require due consideration during paediatric drug development, prescriptions and pharmacovigilance. When drug administration causes problems, healthcare professionals or caregivers may decide to manipulate the dosage form or to give medicines with food or drink, even when this is not recommended in the user information. ${ }^{10} 3951$ However, such handlings may result in altered bioavailability and adverse drug reactions due to, for example, chemical and physical instability. ${ }^{2}$ This further strengthens the need for child and caregiver acceptability testing during (early) paediatric clinical trials and paediatric formulation development as well as for an internationally harmonised methodology for testing the acceptability of paediatric drugs in different age groups. ${ }^{1152}$

\section{CONCLUSION}

Safe and effective paediatric pharmacotherapy requires careful consideration of selecting the type of drug, a suitable dose and an age-appropriate formulation, and the younger the child, the more the attention that is required. The lack of knowledge on the pharmaceutical development and production of medicines for (the youngest) children has been identified as a barrier to essential medicines. Recent global incentives and funding opportunities have resulted in increased research in this domain and in an integrated approach to formulation development. Key aspects involve the development of (novel) dosage forms such as mini-tablets and orodispersible formulations, the safety of excipients, child acceptability and the importance of suitable dosing devices. The acquired knowledge is useful to formulation scientists as well as to doctors, pharmacists and caregivers when prescribing, compounding, dispensing or administering medicines to children. 
Figure 2 Integrated approach to formulation development.

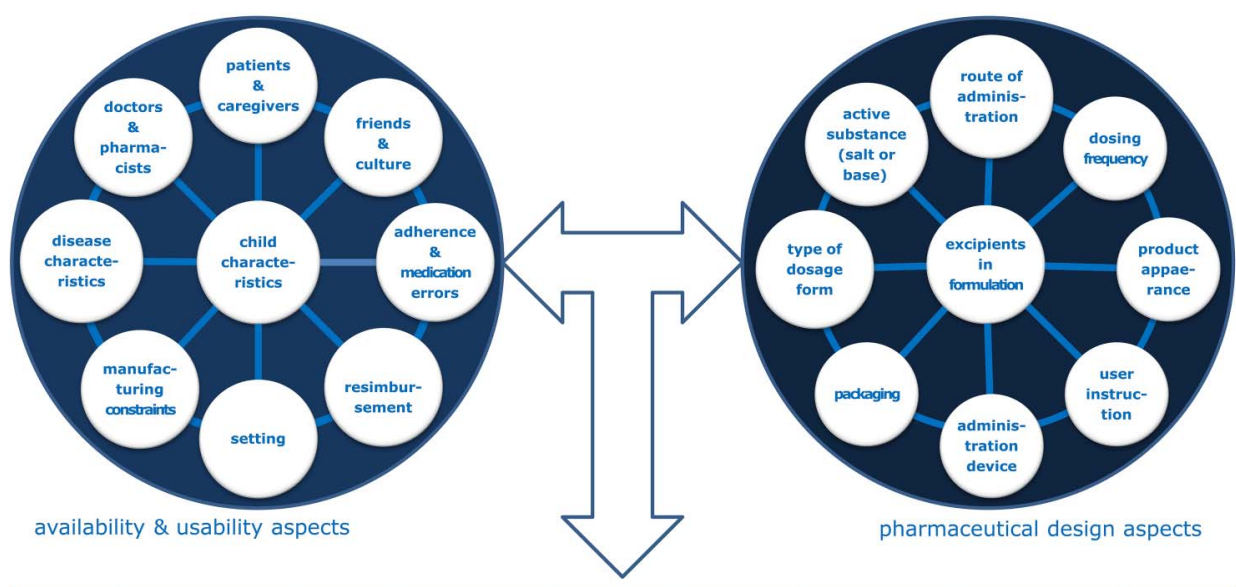

safe \& effective
Contributors This manuscript has been drafted by DAvR-N following the publication of her thesis on child-friendly medicines: availability, pharmaceutical design, usability and patients outcomes. The supervisors of this PhD study were AFAMS, TCGE and her daily supervisor was CMAR. The current review is co-authored by all three members of the DAvR-N PhD team, and in addition by HV, who was assigned as a Utrecht University professor of the reading committee. All four co-authors have carefully read and commented on the draft manuscript and have agreed to the final manuscript as currently submitted.

Competing interests DAvR-N is working for the Medicines Evaluation Board in the Netherlands (MEB) and is a member of the European Medicines Agency's (EMA) Quality Working Party, that is, EMA expert. AFAMS is a board member of the MEB and an EMA expert. TCGE is an EMA expert as well.

Disclaimer The opinions in this article are not intended to reflect the opinions of the MEB or EMA or any of its working parties or committees.

Provenance and peer review Commissioned; externally peer reviewed.

Open Access This is an Open Access article distributed in accordance with the Creative Commons Attribution Non Commercial (CC BY-NC 4.0) license, which permits others to distribute, remix, adapt, build upon this work non-commercially, and license their derivative works on different terms, provided the original work is properly cited and the use is non-commercial. See: http://creativecommons.org/ licenses/by-nc/4.0/

\section{REFERENCES}

1 van Riet-Nales DA, de Jager KE, Schobben AF, et al. The availability and age-appropriateness of medicines authorized for children in The Netherlands. $\mathrm{Br} J$ Clin Pharmacol 2011;72:465-73.

2 Bellis JR, Kirkham JJ, Thiesen S, et al. Adverse drug reactions and off-label and unlicensed medicines in children: a nested case-control study of inpatients in a pediatric hospital. BMC Med 2013;11:238.

3 Novack GD. What does the food and drug administration safety and innovation act mean for you? Ocul Surf 2013;11:206-9.

4 Turner MA, Catapano M, Hirschfeld S, et al. Paediatric drug development: the impact of evolving regulations. Adv Drug Deliv Rev 2014;73:2-13.

5 Watts $\mathrm{G}$. WHO launches campaign to make drugs safer for children. BMJ 2007:335:1227.

6 World Health Organization. Development of paediatric medicines: points to conside in pharmaceutical development. http://www.who.int/medicines/areas/quality_safety/ quality_assurance/Rev3-PaediatricMedicinesDevelopment_QAS08-257Rev3_ 17082011.pdf (accessed 1 Oct 2015).

7 European Medicines Agency QWPPC. Guideline on the pharmaceutical development of medicines for paediatric use. http://www.ema.europa.eu (accessed 1 Oct 2015).

8 van Riet-Nales DA, Schobben AF, Egberts TC, et al. Effects of the pharmaceutical technologic aspects of oral pediatric drugs on patient-related outcomes: a systematic literature review. Clin Ther 2010;32:924-38.

9 Ivanovska V, Rademaker CM, van Dijk L, et al. Pediatric drug formulations: a review of challenges and progress. Pediatrics 2014;134:361-72.
10 Venables $\mathrm{R}$, Batchelor $\mathrm{H}$, Hodson J, et al. Determination of formulation factors that affect oral medicines acceptability in a domiciliary paediatric population. Int I Pharm 2015;480:55-62

11 Ranmal S, Tuleu C. Demonstrating evidence of acceptability: the 'catch-22' of pediatric formulation development. Clin Pharmacol Ther 2013;94:582-4.

12 European Directorate for the Quality of Medicines and Healthcare. Standard terms, 2015. https://standardterms.edqm.eu/stw/controlleterms/communications/O\# (accessed 1 Oct 2015).

13 Tshefu A, Lokangaka A, Ngaima S, et al. Oral amoxicillin compared with injectable procaine benzylpenicillin plus gentamicin for treatment of neonates and young infants with fast breathing when referral is not possible: a randomised, open-label, equivalence trial. Lancet 2015;385:1758-66.

14 Strickley RG, Iwata Q, Wu S, et al. Pediatric drugs-a review of commercially available oral formulations. J Pharm Sci 2008;97:1731-74.

15 Bauters T, Claus B, Willems E, et al. What's in a drop? Optimizing strategies for administration of drugs in pediatrics. Int I Clin Pharm 2012;34:679-81.

16 Walsh J, Bickmann D, Breitkreutz J, et al. Delivery devices for the administration of paediatric formulations: overview of current practice, challenges and recent developments. Int J Pharm 2011;415:221-31.

17 Liu F, Ranmal S, Batchelor HK, et al. Patient-centred pharmaceutical design to improve acceptability of medicines: similarities and differences in paediatric and geriatric populations. Drugs 2014;74:1871-89.

18 Winch PJ, Gilroy KE, Doumbia $\mathrm{S}$, et al. Prescription and administration of a 14-day regimen of zinc treatment for childhood diarrhea in Mali. Am J Trop Med Hyg 2006;74:880-3.

19 Ameen VZ, Pobiner BF, Giguere GC, et al. Ranitidine (Zantac) syrup versus Ranitidine effervescent tablets (Zantac) EFFERdose) in children: a single-center taste preference study. Paediatr Drugs 2006;8:265-70.

20 Lopez FL, Ernest TB, Tuleu C, et al. Formulation approaches to pediatric oral drug delivery: benefits and limitations of current platforms. Expert Opin Drug Deliv 2015; 12:1727-40.

21 Slavkova M, Breitkreutz J. Orodispersible drug formulations for children and elderly. Eur J Pharm Sci 2015;75:2-9.

22 Klingmann V, Seitz A, Meissner T, et al. Acceptability of uncoated mini-tablets in neonates-a randomized controlled trial. J Pediatr 2015;167:893-6.e2.

23 Ceschi A, Hofer KE, Rauber-Luthy C, et al. Paracetamol orodispersible tablets: a risk for severe poisoning in children? Eur I Clin Pharmacol 2011;67:97-9.

24 Rustemkyzy C, Belton P, Qi S. Preparation and characterisation of ultra-rapidly dissolving orodispersible films for treating and preventing iodine deficiency in the paediatric population. J Agric Food Chem 2015;63:9831-8.

25 van Riet-Nales DA, de Neef BJ, Schobben AF, et al. Acceptability of different oral formulations in infants and preschool children. Arch Dis Child 2013;98:725-31.

26 Sazawal S, Dhingra P, Dhingra U, et al. Compliance with home-based fortification strategies for delivery of iron and zinc: its effect on haematological and growth markers among 6-24 months old children in north India. J Health Popul Nutr 2014;32:217-26.

27 Hirve S, Bhave S, Bavdekar A, et al. Low dose 'Sprinkles' - an innovative approach to treat iron deficiency anemia in infants and young children. Indian Pediatr 2007:44:91-100 
28 Klingmann V, Spomer N, Lerch C, et al. Favorable acceptance of mini-tablets compared with syrup: a randomized controlled trial in infants and preschool children. J Pediatr 2013;163:1728-32.e1.

29 Kluk A, Sznitowska M, Brandt A, et al. Can preschool-aged children swallow several minitablets at a time? Results from a clinical pilot study. Int J Pharm 2015:485:1-6.

30 Van de Vijver E, Desager K, Mulberg AE, et al. Treatment of infants and toddlers with cystic fibrosis-related pancreatic insufficiency and fat malabsorption with pancrelipase MT. J Pediatr Gastroenterol Nutr 2011;53:61-4.

31 Kreeftmeijer-Vegter $A R$, de Meijer M, Wegman KA, et al. Development and evaluation of age-appropriate film-coated tablets of levamisole for paediatric use (2-18 years). Expert Opin Drug Deliv 2013;10:293-300.

32 Vanprapar N, Cressey TR, Chokephaibulkit K, et al. A chewable pediatric fixed-dose combination tablet of stavudine, lamivudine, and nevirapine: pharmacokinetics and safety compared with the individual liquid formulations in human immunodeficiency virus-infected children in Thailand. Pediatr Infect Dis J 2010;29:940-4.

33 Nachman S, Zheng N, Acosta EP, et al. Pharmacokinetics, safety, and 48-week efficacy of oral raltegravir in HIV-1-infected children aged 2 through 18 years. Clin Infect Dis 2014;58:413-22.

34 Kayitare E, Vervaet C, Mehuys $\mathrm{E}$, et al. Taste-masked quinine pamoate tablets for treatment of children with uncomplicated Plasmodium falciparum malaria. Int J Pharm 2010;392:29-34.

35 Charkoftaki G, Kytariolos J, Macheras P. Novel milk-based oral formulations: proof of concept. Int J Pharm 2010;390:150-9.

36 Gerrard SE, Baniecki ML, Sokal DC, et al. A nipple shield delivery system for oral drug delivery to breastfeeding infants: microbicide delivery to inactivate HIV. Int J Pharm 2012;434:224-34.

37 Bar-Shalom D. Necessity of rethinking oral pediatric formulations. Clin Ther 2014;36:180-3.

38 Wallace LS, Keenum AJ, DeVoe JE. Evaluation of consumer medical information and oral liquid measuring devices accompanying pediatric prescriptions. Acad Pediatr 2010:10:224-7.

39 van Riet-Nales DA, Ferreira JA, Schobben AF, et al. Methods of administering oral formulations and child acceptability. Int J Pharm 2015;491:261-7.
40 Batchelor HK, Kendall R, Desset-Brethes $S$, et al. Application of in vitro biopharmaceutical methods in development of immediate release oral dosage forms intended for paediatric patients. Eur J Pharm Biopharm 2013;85(Pt B):833-42.

41 Aleksovski A, Dreu R, Gasperlin M, et al. Mini-tablets: a contemporary system for oral drug delivery in targeted patient groups. Expert Opin Drug Deliv 2015;12:65-84.

42 Preis M. Orally disintegrating films and mini-tablets-innovative dosage forms of choice for pediatric use. AAPS PharmSciTech 2015;16:234-41.

43 Walsh J, Cram A, Woertz K, et al. Playing hide and seek with poorly tasting paediatric medicines: do not forget the excipients. Adv Drug Deliv Rev 2014;73:14-33.

44 Nellis G, Metsvaht $T$, Varendi $H$, et al. Potentially harmful excipients in neonatal medicines: a pan-European observational study. Arch Dis Child 2015;100:694-9.

45 Salunke S, Brandys B, Giacoia G, et al. The STEP (Safety and Toxicity of Excipients for Paediatrics) database: part 2-the pilot version. Int J Pharm 2013;457:310-22.

46 European Medicines Agency. Excipients labelling. 2015. http://www.ema.europa.eu/ ema/index.jsp?curl=pages/regulation/document_listing/document_listing_000387. jsp\&mid=WC0b01ac05808c01f6 (accessed 1 Oct 2015).

47 Allegaert K. Neonates need tailored drug formulations. World J Clin Pediatr 2013;2:1-5.

48 Sam T, Ernest TB, Walsh J, et al. A benefit/risk approach towards selecting appropriate pharmaceutical dosage forms - an application for paediatric dosage form selection. Int J Pharm 2012;435:115-23.

49 Batchelor HK, Fotaki N, Klein S. Paediatric oral biopharmaceutics: key considerations and current challenges. Adv Drug Deliv Rev 2014;73:102-26.

50 van den Ban E, Souverein PC, Swaab H, et al. Less discontinuation of ADHD drug use since the availability of long-acting ADHD medication in children, adolescents and adults under the age of 45 years in the Netherlands. Atten Defic Hyperact Disord 2010;2:213-20.

51 Richey RH, Shah UU, Peak M, et al. Manipulation of drugs to achieve the required dose is intrinsic to paediatric practice but is not supported by guidelines or evidence. BMC Pediatr 2013;13:81

52 Ricci BM. Bridging studies in support of oral pediatric formulation development. Int J Pharm 2013:457:323-6. 